REPRODUCTION

\title{
Reproductive and therapeutic cloning, germline therapy, and purchase of gametes and embryos: comments on Canadian legislation governing reproduction technologies
}

\section{Bernier, D Grégoire}

J Med Ethics 2004;30:527-532. doi: 10.1136/jme.2003.002170

In Canada, the Assisted Human Reproduction Act received royal assent on 29 March 2004. The approach proposed by the federal government responds to Canadians' strong desire for an enforceable legislative framework in the field of reproduction technologies through criminal law. As a result of the widening gap between the rapid pace of technological change and governing legislation, a distinct need was perceived to create a regulatory framework to guide decisions regarding reproductive technologies. In this article the three main topics covered in the new legislation are commented on: cloning, germline therapy, and purchase of gametes and embryos. Some important issues also covered in the new legislation, such as privacy and access to information, data protection, identity of donors, and inspection, will not be addressed.

See end of article for authors' affiliations

Correspondence to: L Bernier, Biomedical Ethics Unit, McGill University, 3647 Peel St, Montreal, Canada H3A

1X1; lovise.bernier@mail. mcgill.ca

Accepted for publication 2 June 2003
B ill C-6 was adopted as the new Canadian Assisted Human Reproduction Act on 29 March 2004 and is a result of the widening gap between the rapid pace of technological change and existing governing legislation. The coming into force of its provisions will follow a staged approach. Almost all of the prohibitionsfor example, sections five to nine (except for section eight) came into force on 22 April 2004. Section eight, however, which prohibits the use of reproductive material and in vitro embryos without consent, should come into force at a later date, following the regulations that should soon be developed. In drafting Bill C-6, formerly Bill C-13, ${ }^{2}$ the Ministry of Health had two primary objectives. First, to ensure that Canadians using assisted human reproductive techniques are not compromising their health and safety. Second, to guarantee that promising research involving human reproductive material takes place within a regulated environment. Bill C-6 classifies the activities and procedures related to assisted human reproduction in two categories: prohibited activities and controlled activities. The cloning of human beings and the sale and purchase of human embryos and gametes are some examples of activities specifically banned in the legislation. Other activities are allowed, but regulated by a licensing system. Those regulations cover-for example, the safety of reproductive treatments such as in vitro fertilisation (IVF), donor insemination (DI), and the licensing of certain types of research.

On 9 May 2002, the Canadian Minister of Health introduced the Act Respecting Assisted Human Reproduction in the House of Commons. ${ }^{3}$ This bill was originally introduced as Bill C-56, but died on the order paper when parliament was disassembled on 16 September 2002.*

The bill has been reinstated at the same stage in the legislative process as Bill C-13: an Act Respecting Assisted Human Reproductive Technologies and Related Research. It was slightly amended by the standing committee on health on 12 December 2002. On 28 October 2003 the House of Commons passed Bill C-13 by a vote of 149 to 109 .

On 7 November 2003 the House of Commons completed the second reading. The proposed legislation passed the third reading in the House of Commons and was referred to the senate committee on social affairs, science, and technology. The senate standing committee on social affairs, science, and technology reviewed Bill C-6 and unanimously passed it on 3 March 2004.

The act will be revised within 3 years of the establishment of the new Canadian Assisted Human Reproduction Agency in compliance with section 21 (expected in 2005). A committee from the senate, the House of Commons, or both houses of parliament will then be established by parliament. This committee's role will be to undertake a comprehensive review of the provisions and operation of the act and submit a report including a statement of any recommended changes to the act or its administration (Assisted Human Reproduction Act, ${ }^{1}$ s 70). In this article, we will comment on three main topics covered in Bill C-13: cloning, germline therapy, and purchase of gametes and embryos. Some important issues also covered by Bill C-13, such as privacy and access to information, data

Abbreviations: CIHR, Canadian Institutes of Health Research; CE, Council of Europe; DI, donor insemination; $\mathrm{IBC}$, international bioethics committee; IVF, in vitro fertilisation; $\mathrm{SCH}$, Standing Committee on Health; UNESCO, United Nations Educational, Scientific, and Cultural Organization; WHO, World Health Organization

* In the parliament of Canada, the order paper is the official daily agenda of the House of Commons. The order paper lists all the items that may be brought forward in the House of Commons on that day. 
protection, identity of donors, and inspection will not be addressed in this article. $†$

\section{REPRODUCTIVE AND THERAPEUTIC CLONING}

\section{Reproductive cloning is clearly prohibited by the Assisted Human Reproduction Act. A human clone is defined in section 3 as "an embryo that, as a result of the manipulation of human reproductive material or an in vitro embryo, contains a diploid set of chromosomes obtained from a single-living or deceased-human being, fetus or embryo".}

First, it seems important to state the general position of the Assisted Human Reproduction Act on embryo research. Section 5(1)(b) addresses the prohibition against creating an in vitro embryo for research unless it aims at improving or providing instruction in assisted reproductive procedures. Furthermore, section 10(3)(b) generally prohibits obtaining, storing, transferring, destroying, importing, or exporting in vitro embryos for any purpose including research.

The ministry's position on reproductive and therapeutic cloning as explained in an overview document published by Health Canada, ${ }^{4}$ is partly based on the idea that the scientific component of cloning still requires much improvement because frequent miscarriages, malformations, and early death are observed in animal clones. At present, the whole process puts the clone at risk of serious health and safety consequences. Thus, in the eyes of the Canadian government, significant scientific progress is necessary before the technique will be deemed sufficiently safe.

Furthermore, the Canadian government considers that cloning uses human beings as objects for replication, instead of seeing them as unique persons to be appreciated for their individuality. Cloning can thus be viewed as a breach of human dignity and integrity. When the clone is created from another embryo, the very thought of creating a human being without parents is problematic for Canadian authorities because of the unforeseen and unforeseeable social and psychological consequences. ${ }^{4}$

In its December report, ${ }^{5}$ the Canadian Standing Committee on Health ( $\mathrm{SCH}$ ) expressed the view that the potential adverse effects for the children to be created by reproductive cloning were sufficient reason to ban this technique. ${ }^{5}$ The committee added that therapeutic cloning should also be banned, because it was unsafe and commodified the embryo.

In Canada, there are two influential, although not legally binding, documents on the present topic. In February 2002, the Canadian Institutes of Health Research (CIHR) published recommendations with regard to the funding of stem cell research activities. ${ }^{6}$ The CIHR specifically stated, in section 4.9 of this document, that "research involving any cloning technology would not be eligible for funding."

Also, section 9.5 of the tricouncil policy statement, a Canadian reference document on research ethics, states that it is not ethically acceptable to conduct research involving cloning human beings by any means, including somatic cell nuclear transfer. ${ }^{7}$ Although prohibiting reproductive and therapeutic cloning, both documents refer to a need for extensive scientific progress, discussion, and reflection in this area and both leave the door open to an eventual reconsideration of these positions. It is important to note

†Access to medical and/or personal information about donor(s), associated registries, information related to success rates, and legal standards for the protection of the citizen in different cultural traditions of medical secrecy, ownership of medical data, patient autonomy, and professional liability are examples of matters that should be analysed in future work. that the principles set out in the two documents are only mandatory for researchers and institutions receiving money from those two important funding bodies.

Positions towards cloning, whether therapeutic or reproductive, vary from one country to another. In the United Kingdom (UK) - for example, placing a human embryo that has been created otherwise than by fertilisation in a woman has been made a criminal offence by the Human Reproductive Cloning Act 2001. ${ }^{8}$ At the same time, however, the UK House of Lords modified the Human Fertilisation and Embryology Act, extending its purposes to allow cloning of human embryos to derive stem cells and also making therapeutic cloning possible. ${ }^{9}$ In a report on stem cell research of 13 February 2002, the UK select committee on stem cell research unreservedly endorsed the legislative prohibition on reproductive cloning, stating, however, that therapeutic cloning and the use of cell nuclear replacement for research should continue to be allowed. (This report was produced following the European Parliament request for the UK to reconsider its position on cloning. $)^{10}$ Likewise, in a recent statement, the UK Royal Society also insists on the adoption of a moratorium on reproductive cloning by other nations (even for privately funded iniatives) but specifies, at the same time, that such strategy should not be extended to the cloning of very early embryos for research into the therapeutic potential of stem cells. ${ }^{11}$

Furthermore, in the United States, it was decided that no federal funds would be used for research on the creation of any human embryos or the cloning of human embryos for any purpose. ${ }^{12}$ Each state has the discretion, however, to allow or prohibit research on embryos. At the time of writing, nine states (Arkansas, California, Iowa, Michigan, New Jersey, North Dakota, Rhode Island, South Dakota, and Virginia) have enacted statutes forbidding human cloning (some prohibiting just reproductive cloning and some both reproductive and therapeutic cloning). Missouri forbids the use of public funds for human cloning research and Louisiana's legislation that prohibited reproductive cloning expired in July 2003. ${ }^{13}$ The President's Council On Bioethics (which was created in November 2001 to replace the National Bioethics Advisory Commission) published a report on human cloning in July 2002 in which its members unanimously recommended a legislative ban on reproductive cloning. With regard to therapeutic cloning, a minority (seven members) recommended federal regulation of the use of cloned embryos for biomedical research and a majority (ten members) recommended instead a four year moratorium on cloning for biomedical research with a federal review of current and projected practices of human embryo research, preimplantation genetic diagnosis, genetic modification of human embryos and gametes, and related matters. ${ }^{14}$ Moreover, two controversial bills on cloning are in debate before the American senate. One allows therapeutic cloning while prohibiting reproductive cloning, ${ }^{15}$ and the other prohibits all types of cloning. ${ }^{16}$ In a declaration, President Bush clearly endorsed Bill S 1899, a 2002 version of Bill S245, reiterating its total opposition to any form of cloning. ${ }^{17}$

At the international level the United Nations' General Assembly, in resolution 56/93 of 12 December 2001, established an Ad Hoc Committee, open to all Member States of the United Nations to work on the elaboration of an international convertion against reproductive cloning. Committees and working groups have been working on this issue since, holding meetings, hearings, and consultations in search of a consensus on how to handle this important matter. To this day, important divergences of views remain between and among the delegations involved. ${ }^{18}$ As for the existing documents on the topic, the United Nations Educational, Scientific, and Cultural Organisation's 
(UNESCO) Universal Declaration on the Human Genome and Human Rights states that reproductive cloning shall not be permitted as it is contrary to human dignity; the document fails to comment on therapeutic cloning. ${ }^{19}$ In an April 2001 report on the topic, however, the UNESCO international bioethics committee (IBC) did not condemn therapeutic cloning and recognised instead that human embryonic stem cell research is a topic of considerable interest about which there should be a debate at each national level. ${ }^{20}$ The IBC expressed the view that national authorities should carefully weigh the advantages and risks of new technologies, keeping in mind that nuclear transfer should only be used for therapeutic research.

In a 1998 resolution, the World Health Organization (WHO) stated that it is ethically unacceptable and contrary to human dignity and integrity to use cloning for the replication of human individuals. ${ }^{21}$ In a 1999 report, WHO mentioned that major clinical therapeutic benefits may come from the development of cloning techniques for the production of human tissues and organs from non-embryonic cells without specifically referring to embryonic stem cells and therapeutic cloning. ${ }^{22}$ The World Medical Association, in a 1997 resolution, called on researchers and doctors involved in research not to participate in the cloning of human beings until the issues involved had been fully considered and appropriate controls put into place..$^{23}$

In the European context, the 2000 Charter of Fundamental Rights of the European Union explicitly prohibits the cloning of human beings. ${ }^{24}$ Moreover, the Council of Europe (CE) prohibited the production of human embryos for research purposes in its 1997 Convention on Human Rights and Biomedicine $^{25}$ and banned the cloning of human beings in its 1998 additional protocol to the convention. ${ }^{26}$ Nevertheless, major CE member states have not yet signed the convention-for example, the UK, Ireland, Germany, and Russia nor ratified it-for example, France, Finland, and Italy. ${ }^{27}$

In a resolution on human cloning dated 7 September 2000, the European Parliament states its opposition to therapeutic cloning (specifically referring to research using embryos created by cell nuclear transfer), declaring that it addresses a profound ethical dilemma, irreversibly crossing a boundary in research norms, therefore being contrary to public policy. ${ }^{28}$ The parliament also called on the UK government to reconsider its position on human embryo cloning. ${ }^{10}$ In November 2000, the European Group on Ethics in Science and New Technologies (EGE) of the European Commission adopted an opinion on stem cell research. The group states that it is crucial to place embryonic stem cells research under strict public control via a centralised authority, referring to the UK Human Fertilisation and Embryology Authority as an example. As for the creation of embryos by somatic nuclear transfer, the group considers that going further with this technique is premature. ${ }^{29}$

We believe that the Canadian government and the standing committee on health, in expressing a strong opposition to therapeutic cloning, are being too rigid without providing sufficient reasons to support their position. Their fear of abusive, dangerous, and unsafe use of cloning techniques and their need to find a political compromise has led them to a complete ban of therapeutic cloning rather than the creation of a casuistic legal framework permitting strict but adaptable norms. We think this latter approach would be more appropriate for therapeutic cloning. With therapeutic cloning by somatic cell nuclear transfer, the embryo generated is not implanted in a woman's uterus and will not be allowed further development. The attraction of producing embryonic stem cells lies in the fact that these new cells would be compatible with the cells of the donor of the nucleus, making highly successful transplantation possible. It is not enough to argue that allowing the creation of research embryos would be wrong because it "instrumentalises" human life and treats human being as though they were objects (Health Canada, ${ }^{4}$ p 5). This reasoning implies that embryos are human beings and are, at any stage of their development, entitled to a special treatment that makes them ineligible, without any justification to be used as a means to a therapeutic end.尹

We believe the Canadian government's position on therapeutic cloning should not be driven by doubts and dogmatic moral fears.

The situation is different, however, with regard to reproductive cloning. We believe that the moral and psychosocial arguments often brought against the use of reproductive cloning (possibility of abuse in using the technique, problems of identity for the clones, decisions driven by extreme parental narcissism, etc) would not alone be sufficient for a complete ban of reproductive cloning. Well controlled, this technique could prove to be justifiable and useful in very limited circumstances. Reproductive cloningfor example, could become a valid fertility treatment and an acceptable alternative to the use of donated eggs and sperm if it was shown to be safe for the mother and the fetus. We see a major ethical problem, however, with the necessary steps for making this controversial technique safe for the mother, the fetus, and the future baby. After extensive and successful research on animals, experiments on humans would need to be conducted to confirm some hypotheses. This would mean creating some cloned babies and following their development as guinea pigs. This "instrumentalisation" of human existence would imply sacrificing human lives for science, which clearly goes against human dignity. Given the very limited need for this technique today and the great sacrifices that could be incurred by human beings in bringing it to appropriate safety levels, the prohibition of reproductive cloning endorsed by the Canadian government is therefore justified in our opinion.

\section{GERMLINE THERAPY}

Germline genetic alteration is defined as "altering the DNA of human sperm, eggs, or embryos such that the change can be transmitted to the person's children and all generations to follow" (Assisted Human Reproduction Act, ${ }^{1}$ s 3). Section 5(1) (f) of the Assisted Human Reproduction Act specifically prohibits germline alterations. This technique involves intentional manipulation of human genes to produce certain desired characteristics, therefore it has the potential to lead to the creation of "designer children". This position on germline therapy, as explained in a guide to the proposals for legislation published by Health Canada, ${ }^{30}$ is based partly on the concern that the safety of germline alteration cannot be guaranteed without putting future generations at risk. This safety concern was also outlined in a report of the American Association for the Advancement of Science (AAAS). ${ }^{31}$

As mentioned above, Assisted Human Reproduction Act specifically prohibits germline alterations. This position is consistent with the ones generally expressed at different national levels. For instance, in a 2002 arrangement for national consistency in assisted reproductive technologies, the Council of Australian Governments proposed to ban the alteration of the genome of a human cell if this alteration can

¥This is not the state of the law in the Canadian jurisprudence. In Tremblay $v$ Daigle, [1989] 2 SCR 530, it was submitted that granting the fetus the right to life from the moment of conception sets up a potential conflict with the rights of women to personal dignity, bodily integrity, and autonomy. The court held that the right of women to personal dignity, bodily integrity, and autonomy had to be protected and privileged in those circumstances. That jurisprudence is in concordance with the position held in $R \vee$ Morgentaler, [1988] ISCR 30. 
be inheritable. ${ }^{32}$ In the Netherlands, there is also a bill prohibiting the modification of the genetic material of human germline cells with which a pregnancy is to be induced. $^{30}$ In the United States, the US Council for Responsible Genetics strongly opposes the use of germline gene modification in humans. It states that germline modification is not needed to save lives or alleviate the suffering of existing people but targets instead a population of prospective people. It declares that the cultural impact of treating humans as biologically perfectible artifacts would be both negative and unethical. It therefore calls for a permanent ban on germline gene modification. ${ }^{33}$

At the regional level, the CE states, in its Convention on Human Rights and Biomedicine, that any intervention seeking to modify the human genome may only be undertaken for preventive, diagnostic, or therapeutic purposes and only if it does not aim to introduce any modifications in the genome of any descendant (Council of Europe, ${ }^{25} \mathrm{~s} 13$ ). The 2000 Charter of Fundamental Rights of the European Union says that the prohibition of eugenic practices, in particular those aiming at the selection of persons, should be respected..$^{35}$

Internationally, section 24 of the UNESCO Universal Declaration on the Human Genome and Human Rights specifically refers to germline interventions as a practice contrary to human dignity.

We believe that the Canadian position with regards to germline therapy is too restrictive. The two main arguments against it are that the inheritable genetic modification technique has not yet proven to be safe, effective, appropriate, or efficient and that it could be used for eugenic purposes in subsequent generations.

First, as we expressed in the previous section, we believe that the major progress accomplished by science every day, especially in genetics, calls for a legislative approach less restrictive than formal prohibitions. Indeed, instead of paralysing discussion on the topic for a minimum of 3 years (Assisted Human Reproduction Act, ${ }^{1}$ s 70 ), we believe that the rapid evolution and unpredictability of science call for the establishment of legal control mechanisms. Considerable power could be awarded to the new Canadian agency to this effect.

Second, regarding the purpose of inheritable genetic modifications, therapeutic needs would be the main reason to proceed with germline therapy. In fact, the primary goal of this experimental treatment is to alleviate human suffering and disease by curing disorders for which available therapies are not satisfactory. There seems to be a strong risk, however, that germline alteration techniques used for therapeutic purposes could also be used for enhancement and eugenic purposes. ${ }^{36}$ This could lead to the development of harmful conceptions of normality, which are clearly undesirable and contrary to the ethical tradition of medicine and the values of our society. Germline therapy could-for example, be used to remove genes considered deleterious from the human gene pool. We do not think that this hypothetical future prospect is a sufficient reason, however, for complete prohibition. Again, a comprehensive legal framework, coupled with strong supervision and control mechanisms, could be a proper way of preventing eugenic applications while allowing the needed legislative flexibility.

\section{PURCHASE AND SALE OF GAMETES AND EMBRYOS}

Section 7 of the Assisted Human Reproduction Act provides that no person shall purchase, offer to purchase or advertise for the purchase of sperm, ova, human cells or genes from a donor or a person acting on behalf of a donor. Interestingly, only the purchase of gametes, human cells, and genes is prohibited under the act, their sale has not been specifically banned. This distinction has been made in order to protect the most vulnerable individuals. Nevertheless, the sale of this material will very likely be impracticable as well, because of the existing prohibition regarding purchase.

Section 7(2) specifies that "no person shall purchase, offer to purchase or advertise for the purchase of an in vitro embryo; or sell, offer for sale or advertise for sale an in vitro embryo". This prohibition of commercial transactions involving embryos is mainly based on the very special nature of embryos. The Canadian government believes that since embryos inherently contain the potential of eventually becoming human beings, they should not be treated as commodities or objects (Health Canada, ${ }^{4}$ p 7).

Furthermore, the words "purchase" and "sell" include acquiring or disposing of in exchange for property or services (Assisted Human Reproduction Act, ${ }^{1}$ s 7(4)). Offering free services to donors in exchange for their gametes is thus not permitted under the act. Sperm banks and clinics can, however, continue to operate. The prohibited activity is to pay the donors of the gametes, but they can be reimbursed for their expenditures in accordance with the regulations which will gradually be implemented (Assisted Human Reproduction Act, ${ }^{1}$ sl2 and Health Canada ${ }^{2}$ ).

Prohibitions outlined in section 7 of the Assisted Human Reproduction Act are consistent with the Canadian practice of non-commercialisation of blood, organs, plasma, and other tissues (Health Canada, ${ }^{4}$ p 6). The Canadian Ministry of Health aims to prevent the use of reproductive material as a form of currency that would contribute to the "instrumentalisation" of the human body and the exploitation of financially vulnerable individuals. The prohibitions are based on the fear that children could originate from a commercial agreement. Similarly, the standing committee on health also maintains that commercial transactions involving human gametes or embryos, including barter and exchange, should be prohibited without exception because they are contrary to human dignity (House of Commons of Canada, ${ }^{5}$ rec $12(\mathrm{x})$ ).

In Canada, the tricouncil policy statement states that "in research, it is not ethical to use ova or sperm that have been obtained through commercial transactions, including exchange for service" (Canadian Institutes of Health Research, ${ }^{6} \mathrm{~s}$ 9.2). The Canadian position on the purchase and sale of gametes and embryos is coherent with the idea that the human body, its parts and elements, are inalienable.

In Switzerland, section 119 of the constitution ${ }^{37}$ prohibits the gift of embryos and any commercial transaction involving human germinal material and any resulting products from embryos. In Sweden, section 15 of the Swedish Transplantation $\mathrm{Act}^{38}$ provides that someone who wilfully and for profit, collects, donates, receives, or acts as an intermediary in respect to biological material from a living or a dead human or tissue from an aborted fetus, shall be fined or sentenced to imprisonment for up to 2 years. In Australia, section 23 of the Prohibition of Human Cloning Act, states that it is an offence to intentionally give or receive value for the supply of human eggs, sperm, or embryos (Australian government, $^{32}$ s 23). In the UK, the Human Fertilisation and Embryology Act vests considerable control in the hands of the gametes' providers-for example, possible use, length of storage $^{39}$ : but section 12 (e) of the act prohibits payment for supplying gametes and embryos, unless authorised by directions from the Human Fertilisation and Embryology Authority in accordance with section 23 of the act. It seems, however, that the practice in the UK allows reimbursement of donors' expenses and, in certain circumstances, the allocation of services in compensation for the donation-for example, some women can be offered free IVF treatment in exchange for donating eggs. 
On the international scene, the UNESCO IBC, in its Report on the Ethical Aspects of Human Embryonic Stem Cell Research (UNESCO, ${ }^{20} \mathrm{~S}$ x par 51 at p 14) states that the transfer of human embryos can never be a commercial transaction and that measures should be taken to discourage any financial incentive.

At the regional level, the CE expresses, in section 21 of its Convention on Human Rights and Biomedicine, that the human body and its parts should not, as such, give rise to financial gain. The 2000 Charter of Fundamental Rights of the European Union also states that the prohibition on making the human body and its parts a source of financial gain must be respected. ${ }^{40}$

We recognise that the Canadian government's position regarding the prohibited purchase and sale of gametes and embryos is consistent with what is generally accepted throughout the Western world. We believe, however, that the treatment reserved for embryos and gametes should not be the same.

As for the prohibition on the selling or purchasing of human embryos, this question has to be analysed with regard to the special status of the embryo, which is associated with its own capacity to become a fully developed human being. The importance to be given to this unique status depends upon where we stand on moral grounds and how we evaluate human life. There is an ongoing legal and moral debate about whether human embryos should be classified as persons. In Davis $v$ Davis, the Tennessee Supreme Court declared that frozen embryos could neither be considered persons nor property but were rather sui generis and occupied an interim category because of their potential for human life. $\mathbf{t}^{41}$

Thus, regardless of the issue of personhood and despite cultural, religious, and national differences about the moral and legal status of embryos, we agree with the idea that its unique status justifies, by itself, the view that it should not be considered as a commercial object capable of being purchased or sold.

As for the purchase and sale of gametes, a "consent model" (where individuals accept to give or abandon bodily materials as a gift) currently prevails in opposition to a "property model" ${ }^{42}{ }^{43}$ The very notion of a gift included in the consent process, and generally considered as the only acceptable way when talking about transferring blood, organs, or other human material, implies a real notion of ownership over the material itself. In order to give something, one generally needs to own it first. It thus creates confusion that should be resolved.

We are of the view that the whole idea of prohibiting proprietary rights over body parts or human material should be reconsidered in certain cases. To this end, it is crucial to highlight the difference between donations that can potentially put the donors' health at risk from those that cannot.

In the case of donation of eggs, invasive procedures are often required and involve a health risk to the donor-for example, the required hormonal stimulation of ovaries can cause a serious condition called ovarian hyper stimulation syndrome (OHSS) and can result in serious side effects for some women. This practice could also have permanent effects on the reproductive health of donors (such as theoretical risk of ovarian cancer and/or early menopause). If property rights were to be granted to this type of material, the question of whether individuals should receive compensation for assuming health risks should first be debated. This would require a deep analysis of social justice issues involved in balancing autonomy, individual choice, legislative protection of the

$\ddagger \ddagger T h i s$ is a case which recognises the genetic provider's right to choose or consent to the giff or discarding of frozen embryos, refusing to consider them either person or property. most vulnerable individuals, and possible degrees of harms and benefits of the procedure. These issues have not yet been seriously discussed by Canadian authorities and will not be the focus of this article. Meanwhile, we think that the Canadian government's position of banning the purchase of ova is logical and prudent. The position should only be reconsidered following more comprehensive discussion of these matters.

Nevertheless, the situation is different in the case of the donation of sperm, or other human cells that can regenerate and divide infinitely. Such donations do not require complex intervention, nor do they represent risks to the donors' health. In such cases, the recognition of property rights is not a threat to the individuals' interests but can, instead, be a means to furthering those interests. ${ }^{44}$ Granting property rights to individuals for this type of material, with appropriate control and supervision, could be a logical and equitable solution. It could ensure a better respect for individual autonomy, could help to resolve important shortages and dismantle unsafe underground markets for human bodily material. Such a model would not be contrary to human dignity nor would it present any danger to the donor's health in those specific cases. We thus support the idea of revising the actual property model in relation to some human body material. Limits in the way those new property rights could be exercised, the establishment of proper control, education, safeguards, and precise directions on what property could be considered valuable or not, should be put into place to manage the operation of this new model. ${ }^{4-47}$ We thus think that the Canadian approach is not the ideal legislative approach in that it limits the freedom to purchase all reproductive material without making some relevant distinctions.

\section{CONCLUSION}

Controversial developments in the field of reproductive technologies pressure governmental authorities to legislate and to take action promptly. The announcement-for example, of the first human clone by Clonaid on 26 December 2002-has raised various ethical, legal, religious, and scientific issues. It is an unquestionable fact that assisted human reproduction is an area where control should be enforced in order to limit possible abuses and excesses. Indeed, some techniques such as cloning and germline therapy are not sufficiently perfected, though constantly evolving. The Canadian response to this matter is the Assisted Human Reproduction Act, which prohibits and restricts various activities in this field for a minimum period of 3 years.

We believe that the protection and promotion of human health, safety, dignity, and rights in the use of assisted human reproduction technologies and in related research could be better fulfilled by establishing safeguards and control systems instead of prohibiting promising techniques. It would be more appropriate for an administrative body to ensure an ongoing follow up. To this end, the fundamental aim of the Assisted Human Reproduction Agency of Canada (section 21) is to protect and promote the health, safety, and dignity of Canadians by prohibiting unacceptable practices and regulating adequate conduct in human reproductive research. Granting this licensing and monitoring agency considerable power and freedom could adequately replace the strict legal principles proposed. Rigorous but adaptable safeguards could be developed to guide the agency's actions. It would then allow a clearer and more constructive dialogue between the different players involved instead of temporarily closing the door on social debate and valuable research that could benefit a large part of humanity. 


\section{Authors' affiliations}

L Bernier, Law Faculty and Biomedical Ethics Unit, McGill University, Montreal, Canada

D Grégoire, Law Faculty, McGill University, Montreal, Canada

\section{REFERENCES}

1 House of Commons of Canada. Assisted Human Reproduction Act SC 2004 c2. Ottawa: House of Commons of Canada, 2004; http://laws.justice.gc.ca/ en/A-13.4/2294.html (accessed 21 Jul 2004).

2 Health Canada. Information sheet: implementation of section 12reimbursement of sperm and egg donors' expenditures. Ottawa: Health Canada, 2004; http://www.hc-sc.gc.ca/english/protection/reproduction/ reimbursement.html (accessed 17 Jul 2004).

3 House of Commons of Canada. An Act Respecting Assisted Human Reproductive Technologies and Related Research-Bill C-56. OHtawa: House of Commons of Canada, 2002

4 Health Canada. Proposals for legislation governing assisted human reproduction: an overview. Ottawa: Health Canada, 2001; http://www.hc sc.gc.ca/english/pdf/reproduction/repro_over.pdf (accessed 19 Jul 2004).

5 House of Commons of Canada. Assisted human reproduction: building families. Ottawa: House of Commons of Canada, 2001; http:// www.parl.gc.ca/InfoComDoc/37/1/HEAL/Studies/Reports/healrp01-e.htm (accessed 19 Jul 2004).

6 Canadian Institutes of Health Research. Human pluripotent stem cell research recommendations for CIHR funded research. Ottawa: Canadian Institutes of Health Research, 2002; http://www.cihr-irsc.gc.ca/e/publications/ 1489.shtml (accessed 19 Jul 2004).

7 Medical Research Council of Canada, Natural Sciences and Engineering Research Council of Canada, and Social Sciences and Humanities Research Council of Canada. Tricouncil policy statement-ethical conduct for research involving humans. Ottawa: MRC of Canada, NSERC of Canada, and SSHRC of Canada, 1998; http://www.pre.ethics.gc.ca/english/pdf/ TCP\%20June2003-E.pdf (accessed 19 Jul 2004)

8 Human Reproductive Cloning Act 2001: c 23, 2001

9 Human Fertilization and Embryology Act 1 Nov 1990 (modified 23 Jan 2001 by statutory instrument no 188).

10 House of Lords. Report from the select committee on stem cell research London: Parliament Publications, 2002; http://www.parliament.thestationery-office.co.uk/pa/ld200102/ldselect/ldstem/83/8301.htm (accessed 19 Jul 2004).

11 Royal Society. Human Reproductive Cloning: A statement by the Royal Society. London, January 2003. http://www.royalsoc.ac.uk/files/statfiles/ document-212.pdf (accessed 13 Sept 2003).

12 White House. Embryonic stem cell research: fact sheet. Washington: US Government Publications, 2001; http://www.whitehouse.gov/news/ releases/2001/08/20010809-1.html (accessed 19 Jul 2004).

13 National Conference of State Legislatures. State human cloning laws. Updated 12 Mar 2004 http://www.ncsl.org/programs/health/genetics/rtshcl.htm (accessed 19 Jul 2004).

14 The President's Council on Bioethics. Human cloning and human dignity: an ethical inquiry. Washington DC: The President's Council on Bioethics, Jul 2001:199 and ff http://www.bioethics.gov/reports/cloningreport/ pcbe_cloning_report.pdf (accessed 19 Jul 2004).

15 Human Cloning Ban and Stem Cell Research Protection Act of 2003, Bill S303IS. Introduced in Senate 5 Feb 2003 http://frwebgate.access.gpo.gov/ cgi-bin/getdoc.cgi?dbname $=108$ _cong_bills\&docid $=$ f:s303is.txt.pdf (accessed 19 Jul 2004).

16 Human Cloning Prohibition Act of 2003, Bill S245.Is. Introduced in Senate 29 Jan 2003 http://frwebgate.access.gpo.gov/cgi-bin/ getdoc.cgi?dbname = 108_cong_bills\&docid =f:s245is.txt.pdf (accessed 19 Jul 2004).

17 White House. President Bush calls on senate to back human cloning ban. Washington: US Government Publications, 2002; http:// www.whitehouse.gov/news/releases/2002/04/20020410-4.html (accessed 19 Jul 2004).

18 UN General Assembly. International convention against the reproductive cloning of human beings. Report of the Working Group (A/C -6/58/L.9). NY: UN Publications, October 2003. http://ods-dds-ny.un.org/doc/UNDOC/ LTD/N03/541/51/PDF/NO354151.pdf? Open Element (accessed 13 Sept 2003).

19 United Nations Educational, Scientific, and Cultural Organisation. Universal declaration on the human genome and human rights. Paris: UNESCO, 1997: s 11 http://www.unesco.org/shs/human_rights/hrbc.htm (accessed 19 Jul 2004).

20 United Nations Educational, Scientific, and Cultural Organisation. The use of embryonic stem cells in therapeutic research-report of the IBC on the ethical aspects of human embryonic stem cell research. Paris: UNESCO, 2001; http://portal.unesco.org/shs/en/file_download.php/ 64b7abda57372bdc22570b42c1718f1Ste_mCells_en.pdf (accessed 19 Jul 2004).
21 World Health Organisation. Ethical, scientific and social implications of cloning in human health (WHA51.10). Geneva: WHO Publications, 1998.

22 World Health Organisation. Cloning in human health-report by the secretariat (A52/12). Geneva: WHO Publications, 1999; http:// www.who.int/gb/ebwha/pdf_files/WHA52/ew12.pdf (accessed 19 Jul 2004).

23 World Medical Association. World Medical Association resolution on cloning. Paris: WMA Publications, 1997; http://www.wma.net/e/policy/ c7.htm (accessed 19 Jul 2004).

24 European Parliament, Council of Europe and European Commission. Charter of Fundamental Rights of the European Union 2000;264:1-22.

25 Council of Europe. Convention for the protection of human rights and dignity of the human being with regard to the application of biology and medicine: convention on human rights and biomedicine. Orviedo: Council of Europe Publications, 1997: s 18 (2) http://conventions.coe.int/treaty/en/treaties/ $\mathrm{html} / 168 . \mathrm{htm}$ (accessed $19 \mathrm{Jul} 2004$ )

26 Council of Europe. ETS no 168: Additional protocol to the convention for the protection of human rights and dignity of the human being with regard to the application of biology and medicine, on the prohibition of cloning human beings. Paris: Council of Europe Publications, 1998: s.1 http:// conventions.coe.int/Treaty/Treaties/Html/168.htm (accessed 19 Jul 2004)

$27 \mathrm{http}: / /$ conventions.coe.int/Treaty/Commun/ ChercheSig. asp?NT = 164\&CM =2\&DF = 19/07/04\&CL = ENG (accessed 19 Jul 2004).

28 European Parliament. European parliament resolution on human cloning Brussels: European Parliament, 2000, s2.

29 European Group on Ethics in Science and New Technologies. Opinion no 15: Ethical aspects of human stem cell research and use. Brussels: EGE, 2000: s $2.7 \mathrm{http}: / /$ europa.eu.int/comm/european_group_ethics/docs/ avis15_en.pdf (accessed 19 Jul 2004).

30 Health Canada. Guide to the proposals for legislation governing assisted human reproduction. Ottawa: Health Canada, 2001:3

31 American Association for the Advancement of Science. Human inheritable genetic modifications-assessing scientific, ethical, religious, and policy issues. Washington: AAAS, 2000.

32 Council of Australian Governments. Arrangements for nationally consistent bans on human cloning and other unacceptable practices, and use of excess reproductive technology (ART) embryos. Canberra, April 2002. http:// www.pm.gov.au/news/media_release1588.htm (accessed 13 Sept 2003).

33 Netherlands government. Act Containing Rules Relating to the Use of Gametes and Embryos (Embryos Act). 9 Oct 2001. (In Dutch.)

34 Council for Responsible Genetics. Position paper on human germline manipulation. Cambridge: CRG, 2000; http://www.gene-watch.org/ educational/germline_manipulationPP.pdf (accessed 19 Jul 2004).

35 Council of the European Union. Charter of fundamental rights of the European Union. Nice: CEU, 2000: s 3 (2) http://www.europarl.eu.int/ charter/pdf/text_en.pdf (accessed 19 Jul 2004).

36 Cook-Deegan RM. Symposium: regulating germline therapy-germline gene therapy: keep the window open a crack. Politics Life Sciences 1994;3:217-20 at 219 .

37 Swiss Confederation Federal Constitution 18 Apr 1999 s 119 (2) (d) and (e) http://www.admin.ch/ch/f/rs/101 (accessed 19 Jul 2004).

38 Swedish Transplantation Act 1995: 831. (In Swedish.)

39 United Kingdom Parliament. The Human Fertilisation and Embryology Act 1990:37 http://www.hmso.gov.uk/acts 1990/UKpga_19900037_en_2. htm (accessed $17 \mathrm{Jul} 2004$ ).

40 European Parliament, Council of Europe and European Commission. Charter of fundamental rights of the European Union 2000. Official Journal of the European Communities 2000;264:1-22, http://www.europarl.eu.int/ charter/pdf/text_en.pdf (accessed 19 Jul 2004).

41 Davis v Davis (Tenn 1992) 842 SW2d 588.

42 Nuffield Council on Bioethics. Human tissue: ethical and legal issues. London: Nuffield Council on Bioethics, 1995: ss 9.14 and $13.25 \mathrm{http}: / /$ www.nuffieldbioethics.org/filelibrary/pdf/human_tissue.pdf (accessed 19 Jul 2004).

43 Medical Research Council. Human tissue and biological samples for use in research-operational and ethical guidelines. London: MRC Ethics Series, Apr 2001: s 2.2 http://www.mrc.ac.uk/pdf-tissue_guide_fin.pdf (accessed 19 Jul 2004).

44 Mason K, Laurie G. Consent or property? Dealing with the body and its parts in the shadow of Bristol and Alder Hey. Mod Law Rev 2001;64:710-29 at 725 .

45 Laurie G. Response to the "whose hands on your genes?" consultation of the Human Genetic Commission. London: Human Genetic Commission, 2002: c 8 http://www.hgc.gov.uk/whoygconsultation_responses/graeme_laurie.html (accessed 19 Jul 2004).

46 Davies JL. Property interests in human reproductive material. Genetics Law Monitor 2001; Sept/Oct:6-7.

47 Boulier W. Sperm, spleens, and other valuables: the need to recognise property rights in human body parts. Hofstra L Rev 1995;23:693-733 at 705 . 